\title{
Discussion on Graduation Design Topics for Undergraduates Majoring in Project Management
}

\author{
Mingshun $\mathrm{Li}^{1, \mathrm{a}}$, Qiuju Deng ${ }^{2, \mathrm{~b}}$ \\ ${ }^{1}$ School of Traffic and Transportation Engineering, Changsha University of Science \& Technology \\ Changsha, 410114, China \\ ${ }^{2}$ School of Traffic and Transportation Engineering, Changsha University of Science \& Technology \\ Changsha, 410114, China \\ aemail: 279571178@qq.com , bemail:601156861@qq.com
}

\begin{abstract}
Keywords: project management graduation design tender documents topics
\end{abstract}
\begin{abstract}
The requirement for graduation design of undergraduate students is basic theoretical knowledge that reflect the characteristics of how to complexly and flexibly use all kinds of knowledge learned from different stages at the college, and then make students have a further comprehension about it, meanwhile, it can build students' practical ability of combing theory with practice. For example, the establishment of construction tender document will fully prove the content mentioned above. Through years of in-depth research and teaching practice, taking the establishment of construction tender document as topics for graduation design of the students majoring in project management is a more appropriate choice.
\end{abstract}

\section{Problem Raised}

The major of project management was promulgated in 1998 by the Ministry of Education, which was new and incorporated into the "colleges and universities undergraduate course catalog" , " Project Management Professional Goals of Undergraduate Education and Training Program, Main Courses Teaching Basic Requirements " established by the Project Management Professional Guidance Committee of the Teaching Steering Committee of Civil Program of Higher Education shows " project management professional person is to be trained to adapt to the needs of socialist modernization, moral, intellectual, physical, and aesthetic with a basic knowledge of civil engineering technology and project management, economic and legal, engineer basic training, who has a certain practical ability, innovation ability of senior engineering and management talent, it shows that the project management professional practice of teaching has the important impact in professional training programs. What's more ,the graduation design is a top priority [1][2].

Project management is a management involving the stage of the project and various aspects about the program of capital construction, it based on the whole process of management "as the goal, and actively adapt to the social requirements of the overall management personnel. Project management professional requires the students who can stand the perspective of owners or contractors have their work done, it also need them be familiar with the various stages of work to be done in the infrastructure program and master the corresponding practical work skills. what is a issue in major teaching all the time is that project management students how to precisely take their graduate design topics and make the selection to not only visit students' mastery of their university knowledge, but also enable students to make comprehensive use of the knowledge of the university, meanwhile can be well engaged in practical work on the corner .Through years of in-depth research and teaching practice, taking the establishment of construction tender document as a topics for project management major students graduate design is a more appropriate choice [3] [4].

\section{The Main Content Included in Construction Tender Documents}

According to the road construction tender documents promulgated by the Ministry of Transport of the People's Republic of China (2009), highway engineering standard construction tender documents primarily consist of two major aspects: the first is the business tenders, the second is the 
technical tenders [5].

(1) Business tenders section. It mainly refers to the BOQ that has the price list of engineering quantity, the priced bill of quantities contains BOQ description, description of the tender offer, day-laborers instructions, other instructions, engineering quantity list. While the BOQ includes day work table, temporary valuation table, the contents of the tender offer summary table, BOQ unit price analysis table. In addition , construction tender documents standard formats about highway engineering which Promulgated in 2009 include: Letter of tender and appendix to tender, the price index and weight table, the legal representative of identification and power of attorney, the consortium agreement, the bid bond, project management agencies, and relevant qualification information and letter of commitment.

(2) Technical tenders section. The technical tenders that mainly refers to the construction organization design, includes two parts which is the construction organization design text description and construction design Schedule (Figure). The construction organization design text description includes: the layout and planning of the overall construction organization; assurance system and guarantee of duration of major projects in the construction program, methods and technical measures (particularly focus on the key and difficulty of the implementation plan, the method and its measures); duration assurance system and assurance measures; engineering quality management system and the assurance measures; production safety management system and the assurance measures; environmental protection, soil and water conservation assurance system and assurance measures; civilization construction, heritage assurance system and assurance measures; project risk prediction and prevention, emergency plans. Construction organization design Schedule (Figure) include: overall construction schedule; rate of progress of the sub-project plan (slope map); Engineering management curve; productivity and construction of the periodic table of the sub-project; the construction overall plan; labor schedule; temporary land schedule; external supply of electricity demand schedule; contract shall estimate table.

\section{Knowledge and Its Practical Work Skills Training Involved in Construction Preparation of Tender Documents.}

According to the capital construction program in China , the construction of a project should be completed after the stages about project proposals ,the project feasibility studies, engineering design (including preliminary design, technical design and construction drawing design), project construction bidding, project construction, completion and acceptance of delivery, the operation of the project and the assessment followed ; It is respectively corresponding to these stages to invest estimates, design budget, the modified budget, construction drawing budget, base price, quoted price, project settlement, the budget of the project investment estimates; Knowledge and its practical work skills training related to the construction preparation of tender documents are basically covered with all the various stages of the construction above which involves the management contents about different aspects and different stages [6].

(1) The completion of the project quotation document requires the person who has the ability to carry out the construction budget and the tender offer. So this relates to knowledge of the project budget, tender documents, based price and tender offer involved in the course "project cost "and practical teaching of professional courses "curriculum design on project budget"; And then it comes to project economic feasibility analysis and practical teaching of professional foundation courses on investment estimation knowledge, this is decision-making phase of the project work. Students can successfully complete the offer, engineering construction tender documents. If project management major students can successfully complete the project quotation document, their job skills related to the project cost will been strengthened and gain more training [7].

(2) Filling in schedule of construction organization design (Figure) require the person know the related knowledge of regulatory agencies, construction machinery and equipment, construction organization, temporary construction, engineering, subcontracting and materials prices and price adjustment, which involves basic courses "management science" and professional foundation courses "Introduction of engineering machinery", "building materials" and professional courses "construction organization", "FIDIC conditions of contract management", "project management" courses, especially the construction of the three controls which are the progress of the project 
control, project cost control, quality control, and construction contract management and other aspects of knowledge are covered. [7] [8].

(3) what the completion of major projects about construction program and Construction methods in Construction design text description required is more broader knowledge and more involved courses. For highway construction, it is in terms of major projects construction survey, roadbed construction, protection works, drainage works, culverts and channel engineering, bridge engineering, road engineering, construction program. The determination of construction program and construction methods about these projects involve professional basic and specialized courses (including theoretical courses and practical training part) "surveying", "surveying practice", "soil mechanics and foundation", "engineering structures", "building materials", "construction machinery Introduction"," civil engineering ","introduction of bridge engineering, road engineering", "civil engineering construction" students can hardly perfectly complete this without these courses especially the solid theoretical foundation and practical skills (refers to the practice or course design ) [4].

(4) The determination of equipment mobilization cycle and the way to transport equipment, personnel, materials to the construction site, and the determination of the order of the sub-projects construction, then the arrangement about plane drawings of the construction layout and the calculation about productivity of the sub-projects and the periodic table of construction, and the arrangement for season construction, which are all requiring students to have the theoretical foundation of the course "construction organization" and have a considerable degree of practical knowledge (such as "the curriculum design of construction organization "and" the production practice of construction organization"), otherwise it is very difficult to accomplish [4].

(5) The determination of the preparation about construction schedule and technical measures to ensure the duration requires students to firmly master the knowledge of the professional courses "progress control" and be proficiency in application; while the determination of technical organizational measures to ensure the quality of the project require students to learn professional courses "project quality control" [7].

(6) Of course, students who want to carry out the preparation of tender documents should learn professional courses "project bidding and complete the project bidding curriculum design first. At the same time, the completion of a complete set of tender documents, also requires students master and are very familiar with the knowledge about "engineering insurance "," engineering change" " project claim ", "FIDIC conditions", engineering measurement and payment , that is to say, they must learn and master the entire courses related to the"engineering contract management"[3].

\section{Construction Tender Documentation as a Graduate Design ,its Task Assignments Should be Moderate}

The time for project management undergraduate graduation design is generally about 12 weeks, and is about four months. As a graduation project, students are required to complete the following aspects :

Part I: the original. Including: (1) Chinese and English abstracts, keyword; (2) text (including all contents of business standard component and a technical standard part); (3) References and Acknowledgments; (4) literature review, foreign literature translation; (5) engineering drawings.

Part II: Annex. Including: (1) Calculation chart; (2) the raw data ready to table the budget document; (3) drawings; (4) The title of the report; (5) translation and the original photocopy.

Among them: it requires students to draw eight drawings corresponding to engineering design , including hand-drawn and software-draw; Opening report in the literature review is requiring students to complete the read reference of all books, information and other literature referred graduate design, and then to make a comprehensive elaboration; Foreign literature translation require students to translate foreign materials in an area of expertise, the words of content is no less than 4000.So,in order to complete the graduation project students will have to involve the knowledge about "English", "engineering drawing" course, meanwhile ,it can enable students read more literature about foreign language, translation and writing skills, engineering design drawings drawing skills. While it can finally ensure the full amount of their task[8]. 


\section{Conclusion}

Construction preparation of tender documents as graduation project for students majoring in project management, has wide knowledge related to job skills development and training. Only if students master the professional foundation courses, professional basis courses and professional courses of theoretical knowledge and practical teaching content, and be proficiency in the use of the case, they can complete this part of the graduation project. Although there are facts that certain project bidding is unjust, what makes our students have the ideas "somewhat tender transitions is easily and casual for tenders, bid by the relationship". But through the graduate design training, they recognize that a truly complete set of high-quality tender documents is not easy and the original intention of the implementation of the bidding system is very good. It is believed that with the constant improvement of the bidding system and further standardize about bidding market, the real high quality of the tender documents is the key to win, and in order to achieve this, It is our responsibilities to cultivate the solid management and technical personnel who own professional knowledge comprehensively and professional skills[9].

In summary, taking the establishment of construction tender document as topics for graduation design for students majoring in project management is a more appropriate choice.

\section{Acknowledgment}

This article is funded by the quality courses "project bidding and contract management" (KC1017) which is from Changsha University of Science and Technology.In this writing period, we have got a strong support of the faculty of engineering management in Changsha University of Science and Technology, and taking the papers, monographs, teaching materials and information wrote by the experts and scholars at home or abroad as a reference. Then, thanks for the review and valuable suggestions from these teachers X.Gao, W.A.Yang and Y.Luo who are busy for their working. In short, the authors express a heartfelt thanks to the friends who had participated in helping write and publish papers!

\section{References}

[1] "University undergraduate course catalog" Ministry of Education of the People's Republic of China 1998.

[2]M.S Li ,W.A Yang.et.al: Construction systematic research framework of project management professional practice teaching. Modern Higher Education. Hong Kong, vol.14, pp. 73-74,2005.

[3]M.S Li,Y. Luo .et.al: Construction tender documentation as design engineering management graduate of the suitability of topics. Science Tribune. Wuhan, vol. 4, pp. 158 - 159, 2009.

[4] M.S Li ,Y. Luo .et.al: The research of project management graduation topics. Asia Education. Hong Kong, vol.11, pp. 118 - 119,2003.

[5]Ministry of Transport of the People's Republic of China. Highway engineering standards and construction tender documents (2009). Beijing: People's Communications Press, 2009.

[6] M.S Li,X.Gao.W.A Yang: Interlocking professional Teaching Model.The Science Education Article Collects. Hefei, vol.82, pp. 82 - 83,2008

[7] M.S Li ,X.Gao.et.al: Study the relationship between project management course design. Chinese Journal of Educational Theory. Hong Kong, vol.7, pp. 60 - 61,2002.

[8] M.S Li,X.Gao.et.al: The teaching research of engineering management major courses. Higher Educational Research in Areas of Communications. Wuhan, vol.66, pp. 55 - 56,2003.

[9] M.S Li,X.Gao .et.al: The thinking of engineering management students 'graduation practice. Academic Research. Hong Kong, vol.2, pp. 59 - 60,2003. 